\title{
PENGARUH TABUNGAN DAN DEPOSITO TERHADAP RENTABILITAS BANK PEMERINTAH PERIODE 2008-2011
}

\section{Yuniarti \\ Herman Karamoy}

\begin{abstract}
In Indonesia, banks are important in supporting economic development. It is given that the banking relation with bank institutions have a strategic function primarily as an institution that bridges the parties who have surplus funds to those who need funds. Funds raised from the public in the form of savings and deposits. Banking sector is one factor that the government's attention because the bank is one of the sources of capital that is needed by the community in running its operations. Bank as one of the government's workers are required to successfully develop its participation.

This study uses secondary data published financial statements quartely satae owned banks during the period 2008-2011. This study uses a population of 4 state banks in Indonesia, BNI, BRI, BTN and Bank Mandiri.

The analytical method used was multiple linear regression analysis, and hypothesis testing used for statistical testing of the F test dan t test. By using SPSS Software Version 20.0 for windows.

The results showed that simultaneous saving and deposit significant effect on the rentability of state-owned banks the period 2008-2011. Partially shows that savings variables affect the rentability of state-owned banks. In partial deposit no significant effect on the rentability of state owned banks. Keywords: savings, deposits, and rentability.
\end{abstract}




\section{PENDAHULUAN}

Di Indonesia, perbankan memiliki arti penting dalam menunjang pembangunan ekonomi. Hal ini mengingat bahwa perbankan kaitannya dengan lembaga bank memiliki fungsi yang strategis terutama sebagai lembaga yang menjembatani pihak-pihak yang memiliki kelebihan dana dengan pihak-pihak yang membutuhkan dana. Pertumbuhan dan perkembangan perbankan dari waktu ke waktu menunjukan adanya berbagai peningkatan baik dari segi kelembagaan dan operasional. Himpunan dana masyarakat pun mengalami peningkatan peran ini tentu saja tidak terlepas dari adanya serangkaian kebijakan pemerintah sehingga dapat tercipta kondisi yang dapat memungkinkan perbankan untuk meningkatkan pergerakan dana dari masyarakat.

Sumber dana perbankan yang sebagian besar dihimpun dari dana masyarakat dan merupakan sumber dana yang paling diandalkan oleh bank. Sebagian besar seluruh dana yang dikelola oleh bank merupakan dana pihak ketiga baik berasal dari pemerintah, dunia usaha maupun masyarakat pada umumnya, sedangkan sisanya merupakan modal sendiri dan cadangan modal. Dana yang berhasil dihimpun dari masyarakat biasanya dalam bentuk giro (dana murah) tabungan dan deposito (dana mahal). Simpanan giro merupakan dana murah bagi bank karena bunga atau balas jasa yang dibayar paling murah jika dibandingkan simpanan tabungan dan simpanan deposito. Sedangkan simpanan tabungan dan simpanan deposito disebut dana mahal, hal ini disebabkan bunga yang dibayar kepada pemegangnya relatif lebih tinggi, jika dibandingkan dengan jasa giro sehingga banyak masyarakat yang menanamkan dananya dalam bentuk tabungan dan deposito.

Bank pemerintah memiliki peran ganda yaitu selain untuk memperoleh keuntungan ( Profit Oriented) juga sebagai agen pembangunan (social oriented). Oleh karena itu, bank pemerintah dituntut agar dapat mengelola asset Negara dengan baik. Jika dilihat dari jumlah asset, dapat dikatakan bahwa bank pemerintah merupakan bank dengan jumlah asset terbesar. Aset bank merupakan salah satu indikasi besarnya kepercayaan masyarakat terhadap bank tersebut karena aset adalah kumpulan dana dari masyarakat yang ditempatkan di bank dan kemudian disalurkan sebagai pinjaman dan aset produktif lainnya. Sedangkan laba merupakan salah satu indikasi untuk menilai pengelolaan bank. Dengan adanya rentabilitas yang merupakan kemampuan dari bank untuk memperoleh laba dari aktivitas usahanya yaitu dengan menggunakan asset yang dapat dihitung dengan perbandingan relatif antara laba dan asset yang di gunakan untuk memperoleh laba tersebut yang dikenal dengan Return On Asset (ROA) atau Return On Investmen (ROI) sehingga bank dapat menilai kinerja melalui rentabilitas.

\section{LANDASAN TEORI}

\subsection{Bank}

Menurut Kasmir (2001:25) bank adalah badan usaha yang menghimpun dana dari masyarakat dalam bentuk simpanan dan menyalurkannya kembali kepada masyarakat dan atau bentuk-bentuk lainnya dalam rangka mentarafkan kehidupan dan meningkatkan taraf hidup rakyat banyak. Sementara menurut Rindjin (2003:13) dalam Undang-Undang No.14 pasal 1 bahwa: Bank adalah lembaga keuangan yang usaha pokoknya adalah memberikan kredit dan jasa-jasa dalam lalu lintas pembayaran dan peredaran uang.

Dendawijaya (2005:14) menjelaskan, Bank adalah suatu badan usaha yang tugas utamanya sebagai lembaga perantara keuangan (idke fund surplus unit) kepada pihak yang membutuhkan dana atau kekurangan dana (deficit unit) pada waktu tertentu.

Terdapat tujuan bank yang dikemukakan oleh Verryn Stuart dalam buku Bank Politics dikutip oleh Frianto dkk (2004:11), yaitu:

1. Sebagai perantara kredit yakni bank memberikan kredit kepada pihak ketiga atau debitur yang berasal dari simpanan pihak ketiga (masyarakat).

2. Menciptakan kredit yakni meminjamkan dana yang tidak berasal dari dana masyarakat.

Menurut Kasmir (2008:34) bank dapat dikategorikan sebagai berikut:

a. Dilihat dari segi fungsinya 
Menurut Undang-Undang Pokok Perbankan Nomor 7 tahun 1992 dan ditegaskan lagi dengan keluarnya Undang-Undang RI Nomor 10 tahun 1998 maka jenis perbankan terdiri dari: Bank umum dan bank BPR

b. Dilihat dari segi kepemilikannya

Jenis bank dilihat dari segi kepemilikan tersebut adalah sebagai berikut;

1. Bank milik pemerintah adalah bank yang dalam akte pendirian maupun modalnya dimiliki oleh pemerintah sehingga seluruh keuntungan bank ini dimiliki oleh pemerintah pula.

2. Bank milik swasta nasional, merupakan bank yang seluruh atau sebagian besarnya sahamnya dimiliki oleh swasta

3. Bank milik koperasi, merupakan bank yang kepemilikan saham-sahamnya dimiliki oleh perusahaan yang berbadan hukum koperasi.

4. Bank milik asing, merupakan cabang dari bank yang ada diluar negeri, bank milik swasta asing atau pemerintah asing.

Bank milik campuran, merupakan bank yang kepemilikan sahamnya dimiliki oleh pihak asing dan swasta nasional.

c. Dilihat dari segi status

1. Bank devisa

Bank devisa merupakan bank yang dapat melaksanakan transaksi luar negeri atau yang berhubungan dengan mata uang asing sacara keseluruhan, misalnya transfer keluar negeri, inkaso keluar negeri, pembukuan dan pembayaran Letter of Credit (LC) dan transaksi lainnya.

2. Bank Non Devisa

Bank non devisa merupakan bank yang belum mempunyai izin untuk melaksanakan transaksi sebagai bank devisa, sehingga tidak dapat melaksanakan transaksi seperti halnya bank devisa dan hanya dilakukan dalam batas-batas negara.

d. Dilihat dari segi cara menentukan harga

1. Bank yang berdasarkan prinsip konvansional

Dalam mencari keuntungan dan menentukan harga kepada nasabahnya, bank yang berdasarkan prinsip konvensional menggunkan dua metode, yaitu:

a) Menentukan bunga sebagai harga (spread based) untuk produk simpanan seperti giro, tabungan maupun deposito.

b) Menerapkan berbagai biaya dalam nominal atau persentase tertentu (fee based) untuk jasajasa lainnya.

2. Bank yang berdasarkan prinsip syariah

Prinsip syariah adalah aturan perjanjian berdasarkan hukum islam antara bank dan pihak lain untuk menyimpan dana atau pembiayaan usaha atau perbankan lainnya. Bank berdasarkan prinsip syariah mengharamkan penggunaan produknya dengan bunga tertentu karena diartikan sebagai riba.

\subsection{Pengertian Rentabilitas}

Menurut Harahap (2009:304) rentabilitas adalah kemampuan perusahaan dalam mendapatkan laba melalui semua kemampuan dan sumber yang ada seperti kegiatan penjualan, kas, asset, modal. Sementara menurut Mamduh dan Halim (2007:83) profitabilitas atau rentabilitas merupakan kemampuan perusahaan menghasilkan keuntungan pada tingkat penjualan, asset, dan modal saham tertentu. Ada pun pengertian secara umum yang dikemukakan oleh Sujana (2006), yaitu kemampuan suatu perusahaan untuk menghasilkan keuntungan dibandingkan dengan jumlah modal yang digunakan, dinyatakan dalam persentase. 


\section{a. Tabungan}

Dalam Undang-Undang Perbankan Nomor 10 tahun 1998 yang diuraikan oleh Kasmir (2001:79) tabungan adalah simpanan yang penarikannya hanya dapat dilakukan menurut syarat-syarat tertentu yang disepakati, tetapi tidak dapat ditarik dengan cek, bilyat giro dan atau alat lainnya yang dipersamakan dengan itu.

\section{b. Deposito}

Dalam Undang-Undang Perbankan No 10 tahun 1998 yang diuraikan Kasmir tentang perbankan (2001:85), Deposito adalah simpanan yang penarikannya hanya dapat dilakukan pada waktu tertentu berdasarkan perjanjian nasabah penyimpan dengan bank. Jadi simpanan deposito atau lebih dikenal dengan deposito berjangka adalah simpanan dari masyarakat atau perusahaan yang pencairannya dapat dilakukan setelah jangka waktu yang telah disetujui berakhir.

\section{ANALISIS EVALUASI}

\subsection{Uji Asumsi Klasik Tabungan dan Kredit terhadap Rentabilitas}

1. Uji Normalitas

Ghozali (2009:107) uji normalitas bertujuan untuk menguji apakah dalam model regresi variabel terikat dan variabel bebas keduanya memiliki distribusi normal atau tidak.

Dari tabel 4.1 dapat dilihat bahwa hasil uji normalitas dengan menggunakan analisa statistik uji Kolmogorov Smirnov Asymp sig $>0.05$ maka residual error data adalah normal sehingga model regresi telah memenuhi asumsi uji normalitas.

2. Uji Multikolinearitas

Ghozali (2009:25) Uji multikolinearitas bertujuan untuk menguji apakah dalam model regresi ditemukan adanya korelasi yang tinggi atau sempurna antar variabel bebas/independen. Model regresi yang baik seharusnya tidak terjadi korelasi di antara variabel bebas. Jika variabel bebas saling berkorelasi, maka variabel-variabel ini tidak ortogonal. Apabila terjadi korelasi antara variabel bebas, maka terdapat problem multikolinearitas (multiko) pada model regresi tersebut. Tidak ada variabel bebas yaitu tabungan dan tabungan kredit yang memilki nilai tolerance kurang dari 0,10. Hasil uji VIF juga menunjukan hal yang sama yaitu tidak ada satupun variabel independen yang memiliki VIF lebih dari 10. Sehingga dapat disimpulkan bahwa tidak terjadi multikolinearitas antar variabel bebas dalam persamaan regresi.

3. Uji Autokorelasi

Autokorelasi adalah korelasi (hubungan) yang terjadi di antara anggota-anggota dari serangkaian pengamatan yang tersusun dalam rangkaian waktu atau tersusun dalam rangkaian ruang. Autokorelasi bertujuan untuk menguji apakah dalam suatu model regresi linier ada korelasi antara kesalahan pengganggu pada periode $t$ dengan kesalahan pada periode $t-1$ (sebelumnya). Jika terjadi korelasi, maka dinamakan terjadi problem autokorelasi (Ghozali, 2009:79). Pengujian ini dilakukan dengan menggunakan uji Durbin-Watson (DW-test).

Dari pengujian Durbin-Watson dalam penelitian ini dihasilkan nilai DW sebesar 1.935. Nilai ini dibandingkan dengan nilai tabel menggunakan signifikasi 5\%, jumlah data 64 (n) dan jumlah variabel independen $2(\mathrm{k}=2)$, maka terletak diantara batas atas $(\mathrm{du}=1,65)$ dan batas bawah $(\mathrm{dl}=1,51)$. Oleh karena nilai DW 1.935 lebih besar dari batas atas (du) 1,65 dan kurang dari 2,3383 (4-du) maka dapat disimpulkan bahwa dalam persamaan regresi ini tidak terdapat autokorelasi.

4. Uji Heteroskedastisitas

Ghozali (2001: 69) Uji heteroskedastisitas ditujukan untuk menguji apakah dalam model regresi terjadi ketidaksamaan variance dan residual satu pengamatan ke pengamatan yang lain. Jika variance dari residual satu pengamatan ke pengamatan yang lain tetap, maka disebut homoskedastis dan jika berbeda disebut heteroskedastisitas. Model regresi yang baik adalah yang homoskedastisitas atau tidak terjadi heteroskedastisitas. Cara untuk mendeteksi ada atau 
tidaknya heteroskedastisitas dapat diketahui dengan melihat ada tidaknya pola tertentu pada grafik scatterplot antara nilai prediksi variabel terikat (ZPRED) dengan residualnya (SRESID). Terlihat bahwa dalam persamaan regresi ini tidak terdapat heteroskedastisitas. Hal ini terlihat dari dengan menggunakan Uji Glesjer maka varians data tidak terjadi heteroskedastisitas

\subsection{Analisis Regresi}

Regresi linear berganda digunakan untuk mengetahui adakah pengaruh tabungan dan tabungan kredit terhadap rentabilitas Bank Pemerintah.

Berdasarkan hasil analisis regresi diperoleh koefisien untuk variabel tabungan sebesar -3.0, variabel tabungan dan kredit sebesar 0.254, dan konstanta sebesar -13.265 dari koefisien-koefisien tersebut diperoleh model regresi sebagai berikut:

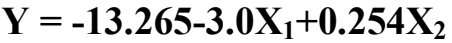

Persamaan regresi linier berganda tersebut di atas dapat di interprestasikan sebagai berikut.

1. Tabungan mempunyai pengaruh negatif terhadap rentabilitas bank. Setiap peningkatan satu satuan, maka akan berdampak pada penurunan rentabilitas bank sebesar 3.0.

2. Tabungan dan kredit mempunyai pengaruh positif terhadap rentabilitas bank. Setiap peningkatan satu satuan, maka akan berdampak pada peningkatan rentabilitas bank sebesar 0.254.

\subsection{Pengujian Hipotesis}

1. Uji Simultan

Uji F digunakan untuk mengetahui ada tidaknya pengaruh secara bersama-sama variabel bebas dengan variabel terikat. Berdasarkan data pengolahan variabel penelitian, uji $\mathrm{F}$ dengan probabilitas value dapat dilihat dari probabilitas value dibandingkan dengan 0,05 hipotesis diterima jika probabilitas $<0,05$.

Pada tabel 4.6 di atas dapat dilihat bahwa hasil uji $\mathrm{F}$ menunjukkan nilai $\mathrm{F}$ hitung sebesar 13.305 dengan signifikansi sebesar 0.000. Nilai signifikansi tersebut lebih kecil daripada 0.05 hal ini berarti secara bersama-sama tabungan dan tabungan kredit mampu mempengaruhi tinggi rendahnya rentabilitas.

2. Koefisien Determinasi

Koefisien determinasi $\left(\mathrm{R}^{2}\right)$ digunakan untuk mengetahui besarnya pengaruh semua variabel indenpenden secara bersama-sama, yaitu tabungan dan deposito terhadap Rentabilitas. Nilai koefisien determinasi sebesar 0.304 atau 30.4\%, yang berarti bahwa rentabilitas mampu dijelaskan oleh tabungan dan tabungan kredit sedangkan sisanya sebesar $69.6 \%$ dijelaskan oleh variabelvariabel lain yang tidak terdapat dalam penelitian ini.

3. Koefisien Korelasi

Koefisien korelasi (R) digunakan untuk mengetahui hubungan antara dua atau lebih variabel independen $\left(\mathrm{X}_{1}\right.$, dan $\left.\mathrm{X}_{2}\right)$ terhadap variabel dependen $(\mathrm{Y})$ secara serentak.Dalam hal ini mengukur hubungan antara variabel independen $\left(\mathrm{X}_{1}\right.$ dan $\left.\mathrm{X}_{2}\right)$ secara serentak terhadap variabel dependen $(\mathrm{Y})$. Nilai $\mathrm{R}$ berkisar antara 0 sampai 1 , nilai semakin mendekati 1 berarti hubungan yang terjadi semakin kuat, sebaliknya nilai semakin mendekati 0 maka hubungan yang terjadi semakin lemah. Dari tabel 4.6 di atas nilai $R$ sebesar 0.551 yang berarti arti bahwa terdapat hubungan yang kuat antara tabungan dan tabungan kredit terhadap rentabilitas Bank Pemerintah.

\subsection{Uji Asumsi Klasik Deposito dan Kredit terhadap Rentabilitas}

1. Uji Normalitas

Ghozali (2009:107) uji normalitas bertujuan untuk menguji apakah dalam model regresi, variabel terikat dan variabel bebas keduanya memiliki distribusi normal atau tidak.

Hasil uji normalitas dengan menggunakan analisa statistik uji Kolmogorov Smirnov Asymp sig > 0.05 maka residual error data adalah normal sehingga model regresi telah memenuhi asumsi uji normalitas. 
2. Uji Multikolinearitas

Ghozali (2009:25) Uji multikolinearitas bertujuan untuk menguji apakah dalam model regresi ditemukan adanya korelasi yang tinggi atau sempurna antar variabel bebas/independen. Model regresi yang baik seharusnya tidak terjadi korelasi di antara variabel bebas. Jika variabel bebas saling berkorelasi, maka variabel-variabel ini tidak ortogonal. Apabila terjadi korelasi antara variabel bebas, maka terdapat problem multikolinearitas (multiko) pada model regresi tersebut.

Tidak ada variabel bebas yaitu tabungan dan tabungan dan kredit yang memilki nilai tolerance kurang dari 0,10. Hasil uji VIF juga menunjukan hal yang sama yaitu tidak ada satupun variabel independen yang memiliki VIF lebih dari 10. Sehingga dapat disimpulkan bahwa tidak terjadi multikolinearitas antar variabel bebas dalam persamaan regresi.

3. Uji Autokorelasi

Dari pengujian Durbin-Watson dalam penelitian ini dihasilkan nilai DW sebesar 1.935. Nilai ini dibandingkan dengan nilai tabel menggunakan signifikasi 5\%, jumlah data 64 (n) dan jumlah variabel independen $2(\mathrm{k}=2)$, maka terletak diantara batas atas $(\mathrm{du}=1,65)$ dan batas bawah $(\mathrm{dl}=1,51)$. Oleh karena nilai DW 2.040 lebih besar dari batas atas (du) 1,65 dan kurang dari 2,3383 (4-du) maka dapat disimpulkan bahwa dalam persamaan regresi ini tidak terdapat autokorelasi.

4. Uji Heteroskedastisitas

Ghozali (2001: 69) Uji heteroskedastisitas ditujukan untuk menguji apakah dalam model regresi terjadi ketidaksamaan variance dan residual satu pengamatan ke pengamatan yang lain. Jika variance dari residual satu pengamatan ke pengamatan yang lain tetap, maka disebut homoskedastis dan jika berbeda disebut heteroskedastisitas. Model regresi yang baik adalah yang homoskedastisitas atau tidak terjadi heteroskedastisitas. Cara untuk mendeteksi ada atautidaknya heteroskedastisitas dapat diketahui dengan melihat ada tidaknya pola tertentu pada grafik scatterplot antara nilai prediksi variabel terikat (ZPRED) dengan residualnya (SRESID).

\subsection{Analisis Regresi}

Regresi linear berganda digunakan untuk mengetahui adakah pengaruh tabungan dan tabungan dan kredit terhadap rentabilitas Bank Pemerintah.

Berdasarkan hasil analisis regresi diperoleh koefisien untuk variabel sebesar sebesar 0.181 , variabel tabungan dan kredit sebesar 1.79, dan konstanta sebesar -7.772 dari koefisien-koefisien tersebut diperoleh model regresi sebagai berikut:

\section{$Y=-7.772+0.181 X_{1}+1.79 X_{2}$}

Persamaan regresi linier berganda tersebut di atas dapat di interprestasikan sebagai berikut.

1. Tabungan mempunyai pengaruh positif terhadap rentabilitas bank. Setiap peningkatan satu satuan, maka akan berdampak pada peningkatan rentabilitas bank sebesar 0.181 .

2. Tabungan dan kredit mempunyai pengaruh positif terhadap rentabilitas bank. Setiap peningkatan satu satuan, maka akan berdampak pada peningkatan rentabilitas bank sebesar 1.79.

\subsection{Pengujian Hipotesis}

1. Uji Simultan

Uji $\mathrm{F}$ digunakan untuk mengetahui ada tidaknya pengaruh secara bersama-sama variabel bebas dengan variabel terikat. Berdasarkan data pengolahan variabel penelitian, uji $\mathrm{F}$ dengan probabilitas value dapat dilihat dari probabilitas value dibandingkan dengan 0,05 hipotesis diterima jika probabilitas $<0,05$.

Hasil uji F menunjukkan nilai $F$ hitung sebesar 13.305 dengan signifikansi sebesar 0.000. Nilai signifikansi tersebut lebih kecil daripada 0.05 sehingga hipotesis $\mathrm{Ha}_{3}$ dapat diterima, hal ini berarti secara bersama-sama deposito dan deposito kredit mampu mempengaruhi tinggi rendahnya rentabilitas. 


\section{Koefisien Determinasi}

Koefisien determinasi $\left(\mathrm{R}^{2}\right)$ digunakan untuk mengetahui besarnya pengaruh semua variabel indenpenden secara bersama-sama, yaitu deposito dan deposito kredit terhadap Rentabilitas.

Nilai koefisien determinasi sebesar 0.319 atau 31.9\%, yang berarti bahwa rentabilitas mampu dijelaskan oleh tabungan dan tabungan kredit sedangkan sisanya sebesar $69.1 \%$ dijelaskan oleh variabel-variabel lain yang tidak terdapat dalam penelitian ini.

\section{Koefisien Korelasi}

Koefisien korelasi (R) digunakan untuk mengetahui hubungan antara dua atau lebih variabel independen $\left(\mathrm{X}_{1}\right.$, dan $\left.\mathrm{X}_{2}\right)$ terhadap variabel dependen $(\mathrm{Y})$ secara serentak.Dalam hal ini mengukur hubungan antara variabel independen $\left(\mathrm{X}_{1}\right.$, dan $\left.\mathrm{X}_{2}\right)$ secara serentak terhadap variabel dependen $(\mathrm{Y})$. Nilai R berkisar antara 0 sampai 1 , nilai semakin mendekati 1 berarti hubungan yang terjadi semakin kuat, sebaliknya nilai semakin mendekati 0 maka hubungan yang terjadi semakin lemah. Dari table 4.14 di atas nilai $\mathrm{R}$ sebesar 0.565 yang berarti arti bahwa terdapat hubungan yang kuat antara tabungan dan deposito terhadap rentabilitas Bank Pemerintah.

\section{PEMBAHASAN HASIL PENELITIAN}

Hasil uji $t$ menunjukan nilai t hitung untuk variabel tabungan sebesar 3.290 dengan nilai signifikansi 0.002. Karena nilai signifikansi lebih kecil dari 0,05 dapat disimpulkan bahwa hipotesis $\mathrm{H}_{1}$ yang menyatakan bahwa tabungan berpengaruh signifikan terhadap rentabilitas pada bank pemerintah diterima. Hal ini menjelaskan bahwa variabel tabungan berpengaruh dalam meningkatkan rentabilitas pada bank pemerintah. Sedangkan hasil uji t untuk variabel deposito menunjukan nilai t hitung sebesar 1.903 dengan nilai signifikansi 0.062 . Karena nilai signifikansi lebih besar dari 0,05 dapat disimpulkan bahwa hipotesis $\mathrm{Ha}_{2}$ yang menyatakan bahwa deposito berpengaruh signifikan terhadap bank pemerintah ditolak. Hal ini menjelaskan bahwa variabel deposito tidak berpengaruh dalam meningkatkan rentabilitas pada bank pemerintah.

Hasil uji F menunjukkan nilai F hitung sebesar 13.305 dengan signifikansi sebesar 0.000 . Nilai signifikansi tersebut lebih kecil daripada 0.05 sehingga hipotesis $\mathrm{Ha}_{3}$ dapat diterima, hal ini berarti secara bersama-sama deposito dan deposito kredit mampu mempengaruhi tinggi rendahnya rentabilitas.

\section{KESIMPULAN DAN SARAN}

Berdasarkan hasil analisis data dan pengujian hipotesis yang telah diuraikan pada bab sebelumnya, maka diperoleh kesimpulan mengenai pengaruh tabungan dan deposito terhadap rentabilitas Bank Pemerintah sebagai berikut :

1. Secara parsial menunjukan bahwa variabel tabungan berpengaruh signifikan terhadap rentabilitas Bank Pemerintah.

2. Secara parsial terhadap variabel deposito tidak berpengaruh signifikan terhadap rentabilitas Bank Pemerintah.

3. Secara simultan tabungan dan deposito berpengaruh signifikan terhadap Rentabilitas Bank Pemerintah. berikut:

Berdasarkan hasil kesimpulan dari penelitian tersebut di atas, maka diajukan saran sebagai

1. Hasil penelitian menunjukan bahwa kemampuan variabel tabungan dan deposito dalam mempengaruhi Rentabilitas Bank Pemerintah masih kurang oleh karena itu diperlukan pengujian lebih lanjut terhadap faktor-faktor lain seperti kebijakan perusahan dalam hal pemberian pinjaman, tingkat pengembalian pinjaman dan lain-lain untuk mendapatkan informasi yang lebih tepat dalam memprediksi tingkat Rentabilitas Bank Pemerintah. 
2. Hasil penelitian juga menunjukan bahwa secara parsial Tabungan tidak memiliki pengaruh terhadap Rentabilitas Bank Pemerintah, jadi bagi pengembangan penelitian selanjutnya agar memperpanjang periode penelitian dan tolak ukur, sehingga dapat diketahui pengaruh Tabungan secara lebih rinci.

3. Diharapkan informasi ini dapat dimanfaatkan bagi pihak-pihak yang berkepentingan dalam hal ini untuk lebih meningkatkan kinerjanya sehingga Rentabilitas Bank Pemerintah dapat lebih ditingkatkan.

\section{DAFTARA PUTAKA}

Amin Widjaja Tunggal, 2000. Dasar-Dasar Analisis Laporan Keuangan, Penerbit Rineka Cipta,Jakarta.

Arif Sogiono dkk, 2010. Akuntansi dan Pelaporan Keuangan Untuk Bisnis Skala Kecil dan Menegah, Edisi Pertama, Penerbit PT. Grasindo Anggota Ikapi. Jakarta

Bambang Riyanto, 2001. Dasar-dasar Pembelajaran Perusahaan, Penerbit BPFE, Yogyakarta

Dwi Prastowo dan Rifka Juliaty, 2005. Analisi Laporan Keuangan Aplikasi, Edisi kedua, Penerbit Akademi Manajemen Perusahaan YKPN

Frianto dkk, 2004. Lembaga Keuangan, Penerbit Rineka Cipta. Jakarta

Fariana Kusumawaji, 2008. Pengaruh Risiko Bank dan Profitabilitas terhadap Harga Saham pada Perusahaan Perbankan. Jurnal Akuntansi, Manajemen bisnis, ISSN 1829-9857.

H. Malayu S.P. Hasibuan, 2006. Dasar-dasar Perbankan. Penerbit PT. Bumi Aksara. Jakarta.

Imam Ghozali. 2009. Ekonometrika: Teori, Konsep, dan Aplikasi dengan SPSS

17. Badan Penerbit Universitas Diponegoro, Semarang.

Intan Cynara Valentina Putri, 2006. Pengaruh Tabungan dan Deposito Terhadap Rentabilitas 20032005. TESIS. Universitas Widyatama Bandung(Tidak Dipublikasi)

Kasmir, 2008. Bank dan Lembaga Keuangan Lainnya.PenerbitPT. Rajagrafindo Persada. Jakarta 2001. Bank dan lembaga Keuangan lainnya. Penerbit PT. Rajagrafindo Persada. Jakarta

Ketut Rindjin, 2003. Pengantar Perbankan dan Lembanga Keuangan Bukan Bank.Penerbit PT Gramedia Pustaka Utama, Jakarta

Lukman Dendawijaya, 2005. Manajemen Perbankan. Edisi Kedua Penerbit Ghalia Indonesia

Mamduh M. Hanafi dan Abdul Halim,2005. Analisis Laporan Keuangan, Edisi kedua, Penerbit UPP AMP YKPN. Yogyakarta.

Mandala Manurung dan Prathama Rahardja, 2004. Uang, Perbankan, dan Ekonomi Moneter. Penerbit Fakultas Ekonomi Universitas Indonesia. Jakarta

Martono dan Agus Harjito,2005. Manajemen Keuangan, Penerbit EKONISIA. Yogyakarta

Mudrajad Kuncoro dan suharjono, 2002. Manajemen Perbankan Teori dan Aplikaki.Penerbit BPFE.Yogyakarta

Suharyadi dan Purwanto, 2007. Statistika Bisnis. Buku II. Salemba Empat. Jakarta

Sunjana Ismaya, 2006. Kamus Akuntansi, Penerbit Pustaka Grafik

Sumarto, Nurmadi H, Yogianto, Evaluasi Kinerja Perusahaan Perbankan yang Terdaftar di Bursa Efek Indonesia dan Thailand, Buletin Ekonomi Perbankan, Volume 3 No. 2 September 2000, hal. 187-207.

Sofyan Syafri Harahap, 2009. Analisis Kritis Atas Laporan Keuangan. Penerbit PT. Rahagrafindo Persada. Jakarta

S. Munawir. 2002. Analisis Laporan Keuangan. Penerbit LibertyYogyakarta

Syamsu Iskandar. 2008, Bank dan Lembaga keuangan.Penerbit PT. Semesta Asa Bersama. Jakarta

Taswan, 2005.Akuntansi Perbankan, Edisi Kedua. Penerbit

Zaki Baridwan, 2004, Intermediate Accounting, Edisi VIII, Penerbit BPFE. Yogyakarta

Website :http//www.idx.co.id. Perusahaan Perbankan Tahun 2008-2011 